\title{
Penerapan Model Pembelajaran Inkuiri Terbimbing dalam Peningkatan Pembelajaran IPS tentang Jual Beli pada Siswa Kelas III SDN 1 Kutowinangun Tahun Ajaran 2017/2018
}

\author{
1,2,3 Universitas Sebelas Maret \\ arbangatunf@gmail.com
}

Arbangatun Fitriana ${ }^{1}$, Tri Saptuti Susiani ${ }^{2}$, Moh. Salimi ${ }^{3}$

\section{Article History}

accepted 01/02/2019

approved 01/03/2019

published 01/04/2019

\begin{abstract}
The objective of this research is to improve social science learning about buying and selling through the implementation of guided inquiry model. This research is a collaborative Classroom Action Research (CAR) conducted within three cycles. Subjects of the research were teacher and the third grade students. Techniques of collecting data were observation, interview, and test. Validity of data in this research was analyzed using triangulation of sources and triangulation of technique. Data analysis consists of data reduction, data display, and drawing conclusion. The results of this research show that the implementation of guided inquiry learning model can improve social science learning about buying and selling for the third grade students of SDN 1 Kutowinangun in the academic year of 2017/2018.
\end{abstract}

Keywords: guided inquiry, learning, social science

\begin{abstract}
Abstrak
Tujuan penelitian ini yaitu untuk meningkatkan pembelajaran IPS tentang jual beli melalui penerapan model pembelajaran inkuiri terbimbing. Penelitian ini merupakan penelitian tindakan kelas (PTK) kolaboratif yang dilaksanakan dalam tiga siklus. Subjek penelitian ini adalah guru dan siswa kelas III. Teknik pengumpulan data menggunakan observasi, wawancara, dan tes. Validitas data menggunakan triangulasi teknik dan sumber. Analisis data meliputi reduksi data, penyajian data, dan kesimpulan. Hasil penelitian ini menunjukkan bahwa penerapan model pembelajaran inkuiri terbimbing dapat meningkatkan pembelajaran IPS kelas III.
\end{abstract}




\section{PENDAHULUAN}

Susanto (2014: 10) menyatakan bahwa, "IImu Pengetahuan Sosial (IPS) adalah bidang studi yang mempelajari, menelaah, menganalisis gejala, dan masalah sosial di masyarakat dengan meninjau dari berbagai aspek kehidupan atau satu perpaduan." Berdasarkan Permendiknas No. 22 Tahun 2006 tentang Standar Isi untuk Satuan Pendidikan Dasar dan Menengah, disebutkan bahwa IPS bertujuan agar peserta didik memiliki kemampuan sebagai berikut: (1) mengenal konsep yang berhubungan dengan kehidupan masyarakat dan lingkungan sekitarnya, (2) dapat berpikir logis dan kritis, memiliki rasa ingin tahu yang tinggi, inkuiri, memecahkan masalah, dan ketrampilan dalam kehidupan sosial, (3) memiliki komitmen dan kesadaran terhadap nilai sosial dan kemanusiaan, (4) dapat berkomunikasi, bekerjasama dan berkompetisi dalam masyarakat yang majemuk.

Berdasarkan tujuan pembelajaran IPS, ketrampilan yang penting untuk dikembangkan adalah ketrampilan meneliti dan berpikir. Ketrampilan meneliti diperlukan untuk mengumpulkan dan mengolah data. Sedangkan ketrampilan berpikir membantu dalam pemecahan masalah dan partisipasi dalam kehidupan masyarakat yang efektif. Ketrampilan berpikir tersebut dapat membantu siswa untuk berpartisipasi secara aktif saat pembelajaran berlangsung (Sapriya, 2015: 52). Proses pembelajaran yang baik mampu mengembangkan cara-cara belajar mandiri dan melibatkan siswa secara aktif, baik dalam perencanaan, pelaksanaan, dan penilaian proses pembelajaran itu sendiri. Oleh karena itu, pengalaman yang diperoleh siswa selama pembelajaran lebih diutamakan sebagai tolak ukur kegiatan. Sementara itu, guru berperan aktif sebagai fasilitator yakni pengelola yang merancang dan melaksanakan kegiatan pembelajaran yang bermakna. Siswa dibimbing untuk menentukan kebutuhan, menganalisis informasi yang diperoleh, menyeleksi informasi penting, dan memberi arti pada informasi baru (Yamin, 2010: 82-83).

Keterlibatan siswa dalam pembelajaran merupakan salah satu indikator pembelajaran yang berkualitas. Susanto berpendapat bahwa kualitas suatu pembelajaran dapat dilihat dari segi proses dan hasil. Dari segi proses, pembelajaran dikatakan berhasil dan berkualitas apabila sebagian besar siswa terlibat secara aktif, baik secara fisik, mental, dan sosial dalam proses pembelajaran seperti: kegairahan belajar yang tinggi, semangat belajar yang besar, dan percaya pada diri sendiri. Dari segi hasil, pembelajaran dikatakan efektif apabila terjadi perubahan tingkah laku yang positif dan tercapainya tujuan pembelajaran yang telah ditentukan (2013: 53-54).

Namun hasil observasi dan wawancara guru kelas III yang dilakukan peneliti pada Sabtu, 4 November 2017 di SDN 1 Kutowinangun diperoleh beberapa fakta antara lain: (1) pembelajaran masih berpusat pada guru (teacher center), (2) cara belajar IPS terbatas pada kegiatan menghafal materi bukan kegiatan mencari dan menemukan makna dari materi yang diajarkan, (3) kegiatan tanya jawab antara guru dan siswa berjalan kurang maksimal, (4) siswa tidak mau mengemukakan pendapatnya saat pembelajaran. Kurang maksimalnya pembelajaran berdampak pada nilai UTS mata pelajaran IPS kelas III yang kurang memuaskan. Dari data yang diperoleh, tingkat ketuntasan sebesar 44,82 \% atau 13 siswa dari 29 siswa mencapai Kriteria Ketuntasan Minimal (KKM). Sedangkan 16 siswa dari 29 siswa atau 55,17\% siswa belum mencapai KKM yang ditentukan yaitu 65.

Berdasarkan kondisi tersebut, peneliti bersama guru berkolaborasi untuk memperbaiki pembelajaran IPS tersebut dengan menerapkan model pembelajaran inkuiri terbimbing.

Sujarwo berpendapat bahwa, "Inkuiri terbimbing merupakan proses pembelajaran dimana pendidik menyediakan bimbingan dan petunjuk yang luas, penentuan masalah dilontarkan oleh pendidik dalam bentuk pertanyaan atau pernyataan 
yang diwujudkan dalam lembar kegiatan peserta didik." Hartono (2014: 61) mengemukakan bahwa inkuiri merupakan model pembelajaran yang dapat merangsang, mengajarkan dan mengajak siswa untuk berpikir secara kritis, analitis, dan sistematis dalam rangka menemukan jawaban secara mandiri dari berbagai permasalahan yang diutarakan. Siswa dituntut untuk berpikir kritis dan analitis untuk memecahkan masalah sehingga siswa tidak hanya mendapatkan pengetahuan secara verbal dari guru, namun siswa secara aktif menemukan sendiri makna dan substansi dari materi yang diajarkan sehingga pembelajaran lebih bermakna bagi siswa.

Bell, et.al (2013: 353-356) yang membagi proses inkuiri menjadi sembilan tahap, yakni: (1) orienting, (2) asking question, (3) hypothesis generation, (4) planning, (5) investigation, (6) analysis and interpretation, (7) conclusion), (8) communication, (9) prediction.

Keefektifan model pembelajaran inkuiri terbimbing telah dibuktikan oleh penelitian yang dilakukan Rahayu (2014) yang menyatakan bahwa penerapan metode inkuiri terbimbing dapat meningkatkan prestasi belajar IPS yang dibuktikan dengan peningkatan pencapaian KKM dan peningkatan keaktifan siswa saat pembelajaran.

Berdasarkan uraian diatas, rumusan masalah penelitian ini yaitu apakah penerapan model pembelajaran inkuiri terbimbing dapat meningkatkan pembelajaran IPS kelas III SDN 1 Kutowinangun tahun ajaran 2017/2018?

Tujuan dari penelitian ini yaitu untuk meningkatkan pembelajaran IPS kelas III SDN 1 Kutowinangun tahun ajaran 2017/2018 melalui penerapan model pembelajaran inkuiri terbimbing.

\section{METODE}

Penelitian ini merupakan penelitian tindakan kelas kolaboratif antara peneliti dengan guru kelas III SDN 1 Kutowinangun tahun ajaran 2017/2018. Subjek penelitian ini adalah guru dan siswa kelas III yang berjumlah 29 siswa. Jenis data penelitian ini adalah data kualitatif berupa penerapan model pembelajaran inkuir terbimbing dan data kuantitatif berupa nilai proses dan hasil pembelajaran IPS. Sumber data dalam penelitian ini yaitu guru dan siswa kelas III. Teknik pengumpulan data menggunakan observasi, wawancara, dan tes. Uji validitas data menggunakan triangulasi teknik dan sumber. Analisis data meliputi reduksi data, penyajian data, dan kesimpulan sesuai model analisis data (Sugiyono, 2015: 338-345).

Indikator kinerja penelitian ini adalah peningkatan pembelajaran IPS dengan ketercapaian target $85 \%$. Penelitian ini memodifikasi prosedur penelitian Kemmis dan Taggart (Arikunto, 2013: 137), yaitu terdiri dari tahap perencanaan, pelaksanaan, pengamatan, dan refleksi.

\section{HASIL DAN PEMBAHASAN}

Penelitian ini dilaksanakan selama tiga siklus dengan menerapkan tujuh langkah model pembelajaran inkuiri terbimbing yaitu: (1) orientasi, (2) merumuskan masalah, (3) mengajukan hipotesis, (4) mengumpulkan dan menganalisis data, (5) menguji hipotesis, (6) membuat kesimpulan, dan (7) mengomunikasikan hasil penyelidikan.

Hasil observasi penerapan model pembelajaran inkuiri terbimbing terhadap guru dan siswa mengalami peningkatan pada setiap siklusnya hingga mencapai indikator kinerja penelitian yang ditargetkan yaitu $85 \%$. Hasil observasi kegiatan guru pada siklus | 70,28\%, meningkat pada siklus II menjadi 80,44\%, dan siklus III mencapai $89,17 \%$, sedangkan kegiatan siswa pada siklus I 65,7\%, meningkat pada siklus II menjadi $75,59 \%$, dan siklus III mencapai 86,8\%. Langkah-langkah penerapan model inkuiri terbimbing yang telah dilakukan peneliti memperkuat sintaks pembelajaran inkuiri terbimbing menurut Thursinawati (2012: 89) yaitu: (1) merumuskan masalah, (2) mengajukan hipotesis, (3) merencanakan dan melaksanakan suatu penyelidikan, (4) 
pengumpulan data dan menginterpretasikan data, (5) membuktikan hipotesis, (6) mengomunikasikan langkah-langkah dan hasil penyelidikan.

Presentase ketuntasan siswa yang dilihat dari proses dan hasil belajar juga mengalami peningkatan pada setiap siklusnya. Persentase ketuntasan hasil belajar pada siklus I 58,61\%, siklus II menjadi 74,13\%, kemudian siklus III mencapai $86,2 \%$. Proses belajar yang meliputi keaktifan, tanggung jawab, dan percaya diri siswa juga mengalami peningkatan pada siklus I memperoleh persentase ketuntasan $63,79 \%$, siklus II menjadi $75,86 \%$, kemudian siklus III mencapai $87,92 \%$. Hal ini memperkuat penelitian Rustini (2009) yang menyatakan bahwa model pembelajaran inkuiri terbimbing cukup efektif untuk meningkatkan kualitas proses dan hasil belajar siswa.

\section{SIMPULAN}

Simpulan dari penelitian ini yaitu penerapan model pembelajaran inkuiri terbimbing dapat meningkatkan pembelajaran IPS pada siswa kelas III, hal ini dibuktikan dari meningkatnya aktivitas guru dan siswa dalam penerapan model inkuiri terbimbing, proses belajar, dan hasil belajar siswa.

Berdasarkan simpulan di atas, peneliti memiliki beberapa saran yaitu guru meningkatkan ketrampilan membimbing diskusi kelompok dan kemampuan memotivasi dalam penerapan model pembelajaran inkuiri terbimbing, sekolah memfasilitasi guru dalam penerapan model pembelajaran inkuiri terbimbing, dan keberhasilan penelitian ini dapat digunakan sebagai dasar pengembangan penelitian yang menerapkan model pembelajaran inkuiri terbimbing untuk meningkatkan pembelajaran IPS .

\section{DAFTAR PUSTAKA}

Arikunto, S. (2013). Prosedur Penelitian Suatu Pendekatan Praktik. Jakarta: PT. Rineka Cipta.

Bell, et al. (2010). Collaborative Inquiry Learning: Models, Tools, and Challenges. International Journal of Science Education, 32 (3), 349-377.

Hartono, R. (2014). Ragam Model Mengajar yang Mudah Diterima Murid. Jogjakarta: DIVA Press.

Permendiknas No. 22 tahun 2006 tentang Standar Isi untuk Pendidikan dasar dan Menengah.

Rahayu, K.D. (2014). Peningkatan Prestasi Belajar IPS melalui Penerapan Metode Inkuiri Terbimbing pada Siswa Kelas V SD Umbulwidodo Ngemplak Sleman. Skripsi Tidak Dipublikasikan. UNY, Yogjakarta.

Rustini. (2009). Penerapan Model Inkuiri dalam Meningkatkan Pembelajaran IPS di Kelas IV Sekolah Dasar. Jurnal Pendidikan Dasar, 1 (1). 68.

Sapriya. (2015). Pendidikan IPS Konsep dan Pembelajaran. Bandung: PT Remaja Rosdakarya

Sugiyono. (2015). Metode Penelitian Tindakan Pendekatan Kuantitatif, Kualitatif, dan $R$ \& D. Bandung: Alfabeta.

Sujarwo. (2011). Model-Model Pembelajaran. Yogyakarta: CV. Venus Gold Press. 